\title{
Urgency of State Administration Innovation System (SINAGARA) on Regional Government Performance
}

\section{Dewi Sartika}

\begin{abstract}
The era of information disclosure is characterized by increasingly sophisticated information technology and well-educated society. That matter has implications for the demands of increasing the quality of public services managed by the government, amid the limitations of the budget, human resources, institutions, and governance. This research encourages the development of the state administration innovation system (SINAGARA) to leverage the performance of regional government. The ways can be taken is to establish an innovation implementation unit/task force where the Regional Research \& Development Agency as the leading sector, provide incentives for tasks unit Innovators and innovator agents and encourage innovation-based budgeting. The importance of building a state administration innovation system (SINAGARA) for regional governments-by utilizing developing information technology - is an indicator of regional head and high leadership performance, and optimizing the role of regional government as the leading sector of development the state administration innovation system.
\end{abstract}

\section{Keywords:}

innovation; innovation system; public administration; SINAGARA; government performance

\section{Introduction}

The development of a region is determined by the level of productivity, which includes innovation as a major meansin improving regional competitiveness. However, unfortunately, governance is one of the slowest elements in responding to social changes, and therefore it is often unable to answer the dynamics of problems that occurred in the society. State administration innovation at least now has been able to answer some of the problems of public services.

The government continues to strive for the bureaucracy to transform from a rulebased bureaucracy to a performance-based bureaucracy. In fact, it is expected that the Indonesian bureaucracy can become dynamic governance in the next 2025 . The complexity of public service problems ranges from complicated and inefficient work processes, the inadequate size and role of the organizational structure, lack of strategic implementation of services, and the low quality and capacity of personnel Human Resources. The problems faced should be solved according to each area of state administration innovation. As one example, to solve complex work processes problems and tend to be inefficient, for example, it can be done through process innovation aimed at improving the quality of work processes to be simpler and more efficient (LANRI, 2015).

In addition, the Minister of the State Apparatus Empowerment and Bureaucratic Reform, Asman Abnur hopes that the State Civil Apparatus will be able to follow the technology

\footnotetext{
- National Institution of Public Administration (NIPA).
} Email: naurah10@yahoo.com 
supporting higher government performance in providing better public services. "High tech must also be followed by high touch. The technology is high, so our touch to technology must be high too. It is not convenient if the technology is high but our touch is low (LANRI, 2017a).

In order to produce quality services, the government should be able to see the strengths and weaknesses that they have in order to make changes in various sectors, either directly or indirectly related to the service. Innovation is needed in order to fix and even improve the quality, efficiency, and effectiveness of public service delivery because it is through innovation that we can create systems, methods, and technologies that will reduce costs, shorten service time, simplify bureaucracy, and most importantly encourage trust to the public in government performance.

As the leading sector of regional innovation development in the context of this paper-State administration innovation -, regional research \& development units should be able to initiate and encourage regional apparatus organizations to constantly innovate in managing public services. However, in some regions, Research \& Development institutions still facing obstacles in managing resources capacity (e.g. quantity and quality of human resources, low interest/ willingness to do research, a lack of additional work income for certain functional positions (researchers), and the absence of research and development networks), research and development capacity (e.g. relinquishment Research and Development affairs to third parties, the lack of regional innovations from Research and Development activities, the need for relevant policy support, and obscurity regarding Research and Development as Regional Apparatus Organization), and dissemination capacity (there have not been much publication research and development results, Research \& Development results have not been utilized as materials for policy making
(PKP2A III, 2016). And the carrying capacity of budget policies is positively correlated with the existence of the research and development in Indonesia (BPP Kemendagri, 2017).

Local governments must innovate (state administration) so that government performance can run more effective and efficient, here meets urgency the importance of building a state administration innovation system (SINAGARA) for local governments - by utilizing developing information technologyto be a performance indicator for regional heads and high leaders and to optimize the role of regional government as the leading sector of development / development of state administration innovation systems.

\section{Methods}

This research is conducted using desk research with qualitative-descriptive analysis. Data collection is done by utilizing secondary data related to the substance of the study. Qualitative research is a method for exploring and understanding the meanings which are ascribed to social and humanitarian problems. One characteristic of qualitative research is trying to make a complex picture of a problem or issue under study.

The stages of analysis are carried out in the following ways: first, collecting literature on the results of previous studies relating to the research theme and supported by various journal articles and relevant books and information. Second, organizing the data obtained to then be sorted according to the theme and focus of the study, translated into units, arranged into patterns, whichever is important to learn. Third, describes in the form of words and descriptive sentences. Furthermore, conclusions are made using the inductive method, namely generalization of various related phenomena and finally the recommendation regarding the development of the State Administration innovation system towards regional government performance. 


\section{Literature Review \\ Public Sector Innovation}

Rogers (2003) defines innovation as "an idea, practice, or object that is considered new by individuals or other adoption units" (p. 35). Therefore, Rogers also emphasizes the novelty aspect of innovation, but-something does not have to be objectively 'new' but must be regarded as new (Bekkers \& Tummers, 2017). Amabile et al. (1996) explains that the root of innovation is creative (p. 1154). "All innovations begin with creative ideas. The successful implementation of new programs, the introduction of new products, or new services depend on someone or a team that has a good idea - and develops the idea beyond its initial conditions." Therefore, innovation is related to certain types of changes (Bekkers \& Tummers, 2017).

Slightly different, Brown and Osborne (2005, p. 4) in (Bekkers \& Tummers, 2017) define public sector innovation as the introduction of new elements into public services - in the form of new knowledge, new organizations and/ or new management or process skills - which represents the discontinuity with the past. This definition highlights a) aspects of novelty (in line with Schumpeter and Rogers), b) aspects of discontinuity (differentiating innovation from change) and c) showing that elements must really be introduced before it is an innovation (showing differences between ideas and creative innovations). While the definition of innovation in the public sector can be classified based on Bekkers, Edelenbos and Steijn (2011, pp. 15-16) as shown in Table 1.

This classification serves as an analytical tool that helps to understand various types of innovation. For example, public management reforms use at least teleworking in organizations, to improve efficiency (reduce office space) and attract young workers (who are accustomed to working in various locations and on different time schedules). From an innovation perspective, teleworking can be seen as organizational and technological innovation. However, this can be accompanied by 'conceptual innovation': a paradigm shift

Table 1.

Classification of public sector

\begin{tabular}{|c|c|c|}
\hline Innovation & Description & Example \\
\hline $\begin{array}{l}\text { 1. Product or service } \\
\text { innovation }\end{array}$ & $\begin{array}{l}\text { Focused on the creation of new public services } \\
\text { or products }\end{array}$ & $\begin{array}{l}\text { Creation of the youth work disability } \\
\text { benefits }\end{array}$ \\
\hline $\begin{array}{l}\text { 2. Technological } \\
\text { innovation }\end{array}$ & $\begin{array}{l}\text { Focused on the invention of new information } \\
\text { and communication and other technologies. }\end{array}$ & Data mining techniques related to 'big data \\
\hline $\begin{array}{l}\text { 3. Process } \\
\text { innovations' }\end{array}$ & $\begin{array}{l}\text { Focused on development and design of the } \\
\text { quality and efficiency of internal and external } \\
\text { policy processes, public service delivery and } \\
\text { administrative processes }\end{array}$ & $\begin{array}{l}\text { Development of a 'one-stop shop' by a } \\
\text { municipality, where citizens can get various } \\
\text { services at one location }\end{array}$ \\
\hline $\begin{array}{l}\text { 4. Organizational } \\
\text { innovation }\end{array}$ & $\begin{array}{l}\text { Focused on creating new organizational } \\
\text { forms, the introduction of new management } \\
\text { methods and techniques, and new working } \\
\text { methods }\end{array}$ & $\begin{array}{l}\text { Introducing teleworking in a public sector } \\
\text { organization }\end{array}$ \\
\hline $\begin{array}{l}\text { 5. Governance } \\
\text { innovation }\end{array}$ & $\begin{array}{l}\text { Focused on the development of new forms } \\
\text { and processes of governance in order to } \\
\text { address societal specific problems }\end{array}$ & $\begin{array}{l}\text { The governance practices to enhance } \\
\text { the self-regulating and self-organizing } \\
\text { capacities of citizens }\end{array}$ \\
\hline $\begin{array}{l}\text { 6. conceptual } \\
\text { innovation }\end{array}$ & $\begin{array}{l}\text { or even to help improve the nature of } \\
\text { problems and solutions }\end{array}$ & $\begin{array}{l}\text { The introduction of the paradigm that when } \\
\text { looking at someone working (dis)ability, } \\
\text { longer analyze physicians what people can } \\
\text { do, but instead of analyzing what they can } \\
\text { still do, then focusing on work abilities is a } \\
\text { potential instead of disability. }\end{array}$ \\
\hline
\end{tabular}

Sources: Bekkers \& Tummers, 2017 
in managers that employees do not need to be directly monitored to check whether they are doing their work.

The successful application of innovation in an environment can be adopted in other environments, meaning that public sector innovation does not stop at one point. This is what diffusion and adoption of innovation by other organizations, as argued by Damanpour and Schneider (2009) in (Bekkers \& Tummers, 2017) that basically two types of innovation processes can be identified: activities that produce innovation and activities that adopt innovation.

Diffusion of innovation is defined as "a process in which innovation is communicated through certain channels from time to time among members of the social system" (Rogers 2003, p. 5) in (Bekkers \& Tummers, 2017). This is closely related to improvement, which can be described as an effort to increase the use of innovation among other actors (Simmons \& Shiffman, 2007) in (Bekkers \& Tummers, 2017). When the diffusion of innovation is successful, various 'adoption' of other innovations. Adoption of innovation is "voluntary processes and/or coercion through which an organization move from initial knowledge of innovation, to form an attitude towards innovation, to a decision to adopt or reject, to implement a new idea, and to confirm this decision" (Rogers 2003, p. 20).

Diffusion and adoption of innovation can be linked with public management reform, public management reform - especially New Public Management (NPM) - has spread to many organizations, sectors, countries, and even continents (Pollitt \& Bouckaert, 2011) in (Bekkers \& Tummers, 2017). Therefore, 'the improvement process has been quite' successful '. It appears that this reform was adopted in various ways. Some countries, such as New Zealand, are taking over far more NPM characteristics than others (such as Belgium or France). Furthermore, other countries were even less enthusiastic and did not take over many aspects of the NPM (such as Germany, against the background because of the traditions of the state and government in Germany which were firmly rooted in 'Rechtstaat').

The character of innovation in the public sector and business sector - which inspires the growth of public sector innovation - is relatively different, which is illustrated in the following matrix.

Requirement the innovating public sector is actually supported by the following logic (Suwarno, 2008) including the first, de-democratization. The phenomenon of democratization has spread throughout the world, crossing the borders of sovereignty, ideology, and politics of nations. Second, international/agreements globalization. International agreements as part of the consequences of globalization and interaction betweennationsin the framework of cooperation. Third, brain drain. The phenomenon of human capital flight that occurs from developing countries to developed countries, so there is an imbalance in the distribution of superior human resources. As a result, the socioeconomic gap between developed countries and developing countries is widening. Fourth, post-conflict countries, democracy, and the transition economy. Some countries have just gone through a period of political conflict and instability due to war or friction in domestic political interests. At this time began to adopt a democratic system and experience a transition. Fifth, oral civil servants. Sixth, oralities become one of the issues of employee integrity in better bureaucratic structuring. Seventh, new sources of competition: privatization and outsourcing. Privatization and outsourcing are organizational phenomena that have penetrated the public sector for a long time. This has an impact on changes in the structure, work culture and dynamic environment of the organization. 
Table 2.

Innovations in the Business Sector and Public

\begin{tabular}{|c|c|c|}
\hline & Business Sector & Public Sector \\
\hline $\begin{array}{l}\text { Organizing } \\
\text { Principle }\end{array}$ & $\begin{array}{l}\text { Efforts to gain profit, stability or revenue } \\
\text { growth } \rightarrow \\
\text { An ever changing market }\end{array}$ & $\begin{array}{l}\text { Enforcement of public policy } \rightarrow \\
\text { New policies and / or changes due to the } \\
\text { political cycle }\end{array}$ \\
\hline \multirow[t]{2}{*}{$\begin{array}{l}\text { Organizational } \\
\text { Structure }\end{array}$} & Organizational sizes vary $\rightarrow$ & $\begin{array}{l}\text { Complex organizational systems, sometimes } \\
\text { in conflict with each other } \rightarrow\end{array}$ \\
\hline & $\begin{array}{l}\text { Large companies usually allocate funds } \\
\text { specifically for innovation }\end{array}$ & $\begin{array}{l}\text { Innovation must be adapted to the complex } \\
\text { situation, including issues of social equity } \\
\text { and economic efficiency }\end{array}$ \\
\hline Performance & Return on Investment $(\mathrm{RoI}) \rightarrow$ & Indicators and performance targets that \\
\hline Measure & $\begin{array}{l}\text { Innovation is a big cost, therefore are usually } \\
\text { calculated from the difference between the } \\
\text { sales gains. }\end{array}$ & $\begin{array}{l}\text { many } \rightarrow \\
\text { Advantages of innovation is very difficult to } \\
\text { measure }\end{array}$ \\
\hline Management issues & $\begin{array}{l}\text { Some managers have some autonomy, } \\
\text { more constrained by shareholder, corporate } \\
\text { governance and or finance } \rightarrow \\
\text { Innovation related to the taking of risks }\end{array}$ & $\begin{array}{l}\text { Most managers are in a situation of political } \\
\text { pressure } \rightarrow\end{array}$ \\
\hline \multirow[t]{2}{*}{$\begin{array}{l}\text { Relationship with } \\
\text { the ends users }\end{array}$} & $\begin{array}{l}\text { The markets are as consumers and also } \\
\text { industry. Feedback from the market is } \\
\text { pushing the idea/innovation } \rightarrow\end{array}$ & $\begin{array}{l}\text { End-users is community, traditionally is a } \\
\text { citizen } \rightarrow\end{array}$ \\
\hline & $\begin{array}{l}\text { Innovation is motivated by the need for } \\
\text { keeping in touch with the market }\end{array}$ & $\begin{array}{l}\text { Customer relation does not awaken properly. } \\
\text { Innovation driven by factors not normally } \\
\text { end-users }\end{array}$ \\
\hline \multirow[t]{2}{*}{ Supply Chains } & $\begin{array}{l}\text { Most companies are part of a larger supply } \\
\text { chain } \rightarrow\end{array}$ & $\begin{array}{l}\text { The public sector depends on the business } \\
\text { sector in the procurement of goods and } \\
\text { services } \rightarrow\end{array}$ \\
\hline & $\begin{array}{l}\text { The resulting innovation smaller companies } \\
\text { typically outdone by big companies, because } \\
\text { it lost in terms of the support fund }\end{array}$ & $\begin{array}{l}\text { Public sector determine standards, business } \\
\text { sector offers innovation }\end{array}$ \\
\hline \multirow[t]{2}{*}{ Human Resources } & Economic motives $\rightarrow$ & Idealistic motives $\rightarrow$ \\
\hline & $\begin{array}{l}\text { Employees are encouraged to making } \\
\text { improvement over products }\end{array}$ & $\begin{array}{l}\text { Innovation is sometimes seen as a threat, } \\
\text { sometimes also as adopted for improvement } \\
\text { of public service }\end{array}$ \\
\hline \multirow[t]{2}{*}{$\begin{array}{l}\text { Source Of } \\
\text { Knowledge }\end{array}$} & $\begin{array}{l}\text { Flexible and wide ranging from consultants, } \\
\text { trade associations, and the public sector } \rightarrow\end{array}$ & $\begin{array}{l}\text { Source of knowledge very much. Relatively } \\
\text { rigid, only some parts of the public sector } \\
\text { which utilizes the University } \rightarrow\end{array}$ \\
\hline & Innovations vary & $\begin{array}{l}\text { Types of innovation in several different parts } \\
\text { of the }\end{array}$ \\
\hline \multirow[t]{2}{*}{ Time Horizon } & Most Short-term $\rightarrow$ & Most Long-term $\rightarrow$ \\
\hline & $\begin{array}{l}\text { Innovation requires a payment as soon as } \\
\text { possible }\end{array}$ & $\begin{array}{l}\text { The difficulty in knowing the consequences } \\
\text { of an innovation }\end{array}$ \\
\hline
\end{tabular}

Source: Suwarno, 2008

The role of government policy related to innovation - according to Albury (2003, p. 4) in (Suwarno, 2008), namely: policy innovation: new policy direction and initiatives (policy innovation); innovations in the policy-making process (innovation in the policymaking process); policy to foster innovation and its diffusion (policies for promoting innovation and dissemination).

With regard to the motives of public sector innovation in a survey research by Borin (2001) in (Suwarno, 2008) it was characterized, 
among others; by 50\% innovation in the public sector is an initiative of the staff front line and middle manager; $70 \%$ of the innovation produced is not a response to the crisis; $60 \%$ of innovations (cross-organizational boundaries cut across organizational boundaries); Innovation comes more because of the motivation to be recognized or valued (recognition) and pride rather than just financial rewards.

\section{Public Administration and Public Service Innovation}

In the Republic of Indonesia Law No. 18/2002 concerning the National System for Research, Development and Application of Science and Technology, the term innovation itself is defined as research, development and / or engineering activities aimed at developing practical application of values and the context of new knowledge, or new ways to apply existing science and technology to products or production processes. It has been explained that the national innovation system is a system of interaction between the institutional elements of science and technology that is directed at producing science and technology in the national scope. The interaction between these elements as a whole aims to develop, protect, finance, or regulate new science and technology to improve the quality of life and sustainable economic growth. However, the implementation of the national innovation system concept, especially in Indonesia, seems to still be more aimed at the interests of economic growth. The innovations developed are still aimed at the interests of the industrial sector because they are more significant in generating economic growth. Innovations directed in the form of appropriate technology needed by the grassroots community have not been properly developed and seem to be left to the market mechanism.

While innovation according to Government Regulation No. 38/2017 is all forms of renewal in the implementation of regional governance, regional innovation targets are directed at accelerating the realization of community welfare through improving public services, empowering and participating in the community and increasing the competitiveness of the region itself. Through Government Regulation No. 38/2017, the government wants a renewal in the administration of regional government not only in reform internal but also in renewing public services so that they can be enjoyed by the people of the area.

In order to produce quality services, the government must be able to see the strengths and weaknesses it has in order to be able to make changes in various sectors both directly and indirectly related to services. Innovation is needed in order to improve and even improve the quality, efficiency, and effectiveness of public service delivery because, through innovation systems, methods and technologies can be created that can reduce costs, shorten service time, cut down bureaucracy, and most importantly provide trust for the public to government performance. The mindset of apparatus public servants, legal support, utilization of information technology, a synergy of policies also contribute to the quality of public service money determines public satisfaction as stakeholders (LANRI, 2017a).

In line with that, the State administration innovation expert, Tri Widodo, explained the innovation of State administration as a change that brought significant improvements to the administration of government on all fronts. In other words, the system of innovation in State administration as an interconnection system between innovation systems resides in the body of government, which then mediates the acceleration of the usefulness and integration of regional innovation systems (Utomo, 2017).

State administrative innovation models include institutional and natural resource innovation models, public service innovation models and governance innovation model. 
Organizational restructuring initiatives as an institutional arrangement of government agencies can be an example of institutional and resource apparatus innovation if it has an impact on creating the best economies of scale, improving the performance and distribution of tasks and responsibilities among employees and ensuring career and future guarantees. With cross-functional integration, if it impacts on increasing resource efficiency, reducing miscoordination between work units, institutional changes need to be implemented.

Leadership education and training are prerequisites for structural stakeholders in the government. Since 2013, there has been a change in the pattern of education and training at all levels - known as New Pattern Leadership Training - an example of innovation in Apparatus management.

Some innovations are tucked into innovation in the leadership training curriculum (Utomo, 2017) including experiential learning, an concept adaptive leadership that emphasizes informal leadership and the development of leadership capacity at various levels and shared leas and the ultimate goal of printing a reformative and transformative leader who is able to accelerate the innovation and performance of his local government.

Public service innovation can also be initiated from the need to bring public services closer to the community. The simplest form is creative administration such as designing reading corners and friendly corners of nursing mothers in the service unit. This can only be presented by creative people and creative milieu. For example, movement 99 innovation in the organization of Apparatus Study and Education Center and Training III in Samarinda, where every employee is required to make at least one innovation within the scope of work, able to foster a culture of creativity in the work environment to support performance without budget-based (LAN, 2018).

\section{State Administration Innovation and Local Government Performance}

Writing about innovation and government performance was written first by (Simon, p. 1937) and (Selznick, p. 1950) in (Suwarno, 2008). Public sector innovation requires a rapid response to any changes from external dynamics and demands that are so fast outside of public organizations. Critical points obtained are problems that occur around efforts to implement information and communication technology (ICT) in government agencies. The performance of local government can be improved from the way out the culture of innovation in the public sector. This was echoed by the United Nation's Department of Economic and Social Affairs (UNDESA) by launching the United Nation's Public Service Awards since 2003, where the award was designed to enhance the role, professionalism and visibility of public services with three basic categories, namely transparency and accountability, improvement of public services and the application of ICT or e-government.

The dimensions of innovation are strongly interspersed with organizational performance but not only related to the budget (input) but also non-financial aspects that are indirect and intangible (Sartika, 2015). Such as value creation innovation to support performance through core values and organizational code of ethics, building a knowledge sharing forum. In another perspective, government organizations as pure non-profit organizations have a performance dimension -in addition to the dimensions of innovation - not only based on budget/financial (input) but also non-financial aspects intangible and indirect. Assessment is not only in the input group but also in the input-output analysis, analysis of results, and benefits, both positive and negative impact analysis, financial analysis and policy analysis. The formulation of the system must load comprehensively.

Bantaeng City Government, South Sulawesi under the leadership of Regent Ir. 
Nurdin Abdullah, who succeeded in utilizing solar energy for city traffic control lights, prioritized infrastructure development for easy access to remote areas, is an example of innovation that leverages the performance of local governments marked by a significant increase in Regional Original Income. From 14.69 billion in 2009 to 54.91 billion in 2015 (Era.id, 2018).

The spirit of appreciation for innovation has grown and even has a regulatory umbrella, which includes the Minister of Administrative Reform and Bureaucratic Reform Regulation No. 5/2019 concerning the Public Service Innovation Competition within Ministries/ Institutions, Regional Governments, StateOwned Enterprises, and Business Entities Regional Ownership. Call it the Ministry of Home Affairs with the Innovative Government Award, the Ministry of Administrative Reform and Bureaucratic Reform with One Institution One Innovation, and so on. Previously, Government Regulation No.38/2017 concerning Regional Innovation has been issued, which aims to improve the performance of regional government administration.

The need for innovations in State administration in the implementation of the regional government, which interconnects the system with the performance of regional governments. It is this state administration innovation spirit that must be owned by public officials, and with theimplementation of leadership training aimed at producing change leaders at all levels, stretching public sector innovations and the strong commitment of regional leaders in presenting quality development and public services and better quality policies will increase with the birth of innovations from Sabang to Merauke (Government, 2014) in the network system of state administration innovation. This research intends to explain the urgency of the system of innovation in State administration in its efforts to improve the performance of regional governments.

\section{Results and Discussion}

The innovation system that was first built was SIDA or Regional Innovation System which aims to accelerate regional development and make the regional government program successful. This is because each region and region has different strategies for developing innovation policies because of the specific challenges and local potential that vary in each region.

The issuance of Government Regulation No. 38/2017 concerning Regional Innovation, which has been enacted since promulgated on September 15, 2017 (Humas, 2017), becomes a legal umbrella for regional innovators in realizing regional innovation goals desired by the central government, namely increasing efficiency, improving effectiveness, improving service quality, does not cause a conflict of interest, is oriented to the public interest, etc. Where the proposed regional innovation initiative according to Government Regulation No. 38/2017 can be done by the Regional Head; Regional Representative Council members; State Civil Apparatus; Regional Apparatus and community members, and the results of proposed regional innovation initiatives are deemed feasible if they meet the following criteria: First, contain renewal of all or part of the elements of innovation. Second, Giving benefits to the region and/or community. Third, does not result in imposition and/or restrictions on the community that is not in accordance with the provisions of the legislation. Fourth, it is government affairs that are the authority of the region. Fifth, it can be replicated. Regional innovation initiatives must be complemented by regional innovation proposals which include, among others; form of regional innovation; designing regional innovations and the main changes that will be made; regional innovation goals; benefits obtained; time of regional innovation trials; budget if needed. Regional innovation initiatives that are in accordance with the criteria and 
supplemented with proposals and review studies by those in charge of research and development convey the regional innovation initiatives to the regional head. In the case of regional innovation initiatives originating from community members submitted to the chairman of the Regional Representative Council and the chairman of the Regional Representative Council will forward them to the regional head to be evaluated by regional officials in charge of research and development. In the event that the evaluation results from regional innovation initiatives are declared feasible as regional innovations if they are in accordance with the criteria referred to above. In evaluating regional innovation initiatives, regional instruments in charge of research and development can involve universities, experts, or practitioners.

An idea of maximizing regional innovation systems (Simbolon, 2017) is motivated by industry-based economic shifts towards a knowledge-based economy (literacy); regional competitiveness is determined by the ability to maximize human capital through innovation; dynamic market characteristics, global competition, network trends, high-wage workforce position, broad multidisciplinary skills, multitalented learning, collaborative management of human resources, and lack of entrepreneurial spirit in society.

From the release of the World Intellectual Property Organization (WIPO), Indonesia's global innovation index was only ranked 100 (out of 141 countries), previously ranked 99 (out of 125 countries), below the ranks of other Southeast Asian countries, such as Thailand (32), Brunei (53), and Malaysia (32). The index is published by INSEAD business schools or the Européen d'Administration des Affaires Institute and the World Intellectual Property Organization (WIPO), under the auspices of the United Nations.

Strengthening the innovation system is motivated by conditions, among others, first, the limited understanding of policymakers and stakeholders about innovation systems; second, the limitations of expertise, practice or examples of success, and practitioners in encouraging movements that can significantly influence the development of innovation systems in various fields, regions and/or levels/contexts. Third, there is no integration of the development of innovation systems in development. Innovation policies that essentially require sectoral policy coherence, national-regional policies, and innovation system governance will not be effective if science and technology policies and other development policies are still partial, fragmented, inconsistent and even contrary to each other. Fourth, the limited data and indicators of quality information systems as a basis for monitoring, and evaluation, as well as learning and policy improvement processes. Fifth, various weaknesses in the innovation system that really need a better policy solution. Innovations generally appear sporadically and in low intensity/frequency (Ismiatun, 2015). Several factors that influence the development of the innovation system: the basis of the system of science and technology (science and technology, including research, development and engineering) and production systems in the economy, along with the interactions that occur in them and among them; socio-cultural development that develops in its society; Regional-oriented innovation systems are the key to the success of the development of research and its applications which are the focus of regional development; equitable development can be pursued through optimizing regional capacity (Ismiatun, 2015).

As mandated by Law No. 32/2004 concerning regional autonomy, the aim of regional autonomy is to improve welfare, public services, and regional competitiveness (article 2 paragraph 3 ). Thus, the regional innovation system is an important part of national development - as important as the support of the State-Administrative Innovation System. 
Joint Regulation of the Minister of Research and Technology No. 3/2012 and Minister of Home Affairs No. 36/2012 concerning Strengthening the Regional Innovation System aims to strengthen regional innovation systems as a focus of regional development in improving the economy and national competitiveness. The priority focus of strengthening the regional innovation system is to build policy coherence in the development of industrial clusters in the region. The essence of the innovation system is a system or a unit of various elements or elements (actors, institutions, relationships, networks, interaction processes, and policies) that influence the direction of development and the speed of innovation, diffusion of innovations and learning processes that occur in a country or region. This system covers the fields of science, technology, and innovation (Ismiatun, 2015). The functions of research and development institutions still need to be improved (PKP2A III, 2016). Changes in governance and the dissemination of innovations at the local level are actually initiated by Research \& Development institutions. The absence of such a significant role impacts the problems faced by government agencies and the local government does not find a solution.

Looking at the productivity level of regional innovation, there are actually many variants and concepts of innovative ideas that emerge every year, which come from the results of changes in employee projects in each Regional Work Unit that has participated in Leadership Training. The change project is actually an innovation work designed to answer the problems that arise in each of its institutions, not only that it also contributes to the performance of the local government and the progress of the region.

Based on Figure 1 above it can be seen that $40 \%$ of the scope of the change project benefits is felt by the wider community, and $23.3 \%$ is beneficial for several stakeholder groups, and $21.7 \%$ is only useful in the internal organizational environment. For the organization itself, the benefits of the presence of a change project include increasing the quality of work (improvised quality), making efficient use of work time, increasing the work

Figure 1.

Reach the benefits of innovation in education and training projects

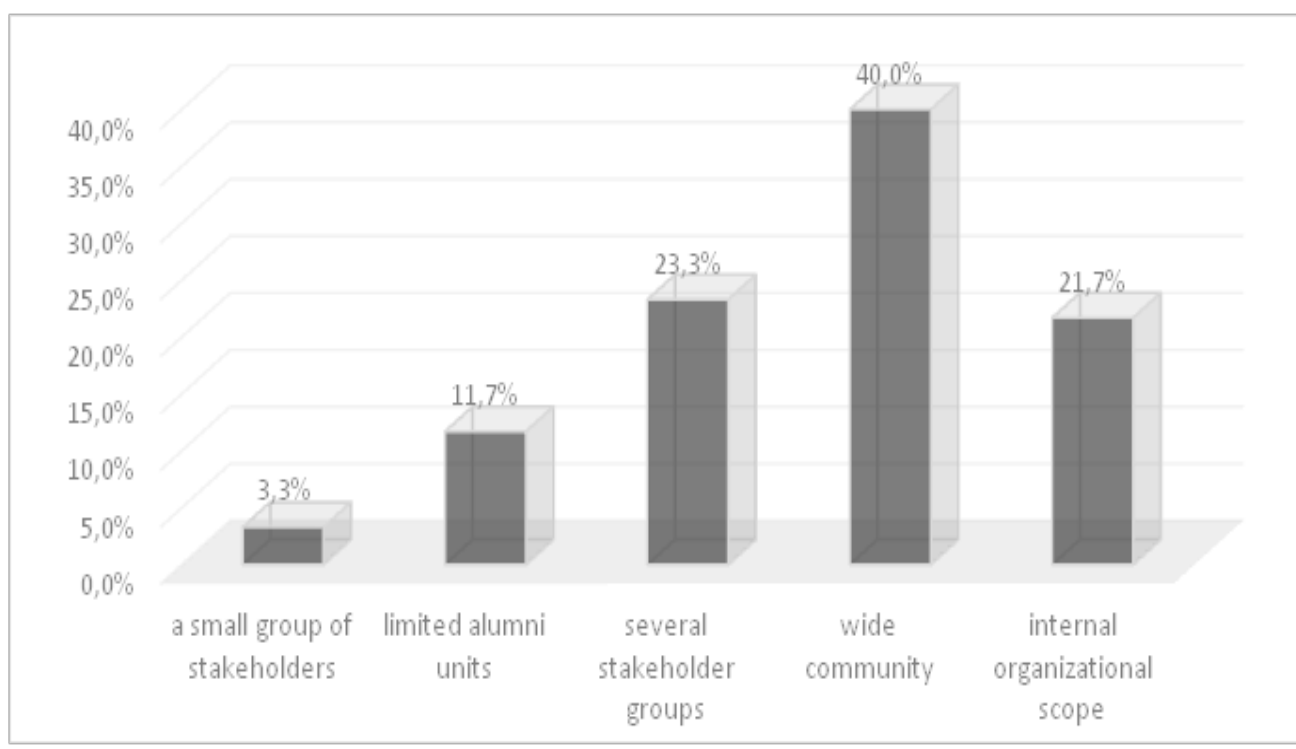

Source: Study of Mapping of Utilization of Post-Training Leadership Change Projects (PKP2A III, 2017). 
performance of led units, and reducing work errors (reduce errors). The existence of a change project has an impact (impact), among others:

1. The alumnus change project has provided an increase in the regional economy through efforts to increase the productivity and creative economy of the community;

2. Increased accountability of regional government performance, marked by more accurate optimization of regional planning, tighter supervision of public services, improvement in apparatus performance, and increased community participation in development;

3. The quality of public services increases marked by improved public service performance, public service officers who work more professionally, more openness and provision of public information, and easier access to public services.

It is expected that a number of these innovative products can be utilized sustainably, documented and become replications as benchmarks elsewhere. However, the fact is not the case. The results of the PKP2A III LAN study state that change projects are not sustainable because of the transfer and promotion of work from alumni to new positions, besides that the budget and resources (infrastructure and human resources) are still limited (PKP2A III, 2017).

Based on Figure 2 above shows that innovation products are still very dependent on individuals/personnel management. Some of the innovations from the Leadership Training change project can indeed run well, but the concept still cannot be a benchmark in other places because there are no institutions or media that can bridge between related work units to be able to adopt the innovation so that the implementation of innovation is still local. The lack of breadth of the usefulness of the innovation projects produced and the lack of sustainability of the innovation project changes are important signals for local governments to be able to revitalize the role of regional Research \& Developmnet institutions. The significant role of the regional

Figure 2.

Inhibiting Factors for Innovation Sustainability Leadership Training change projects

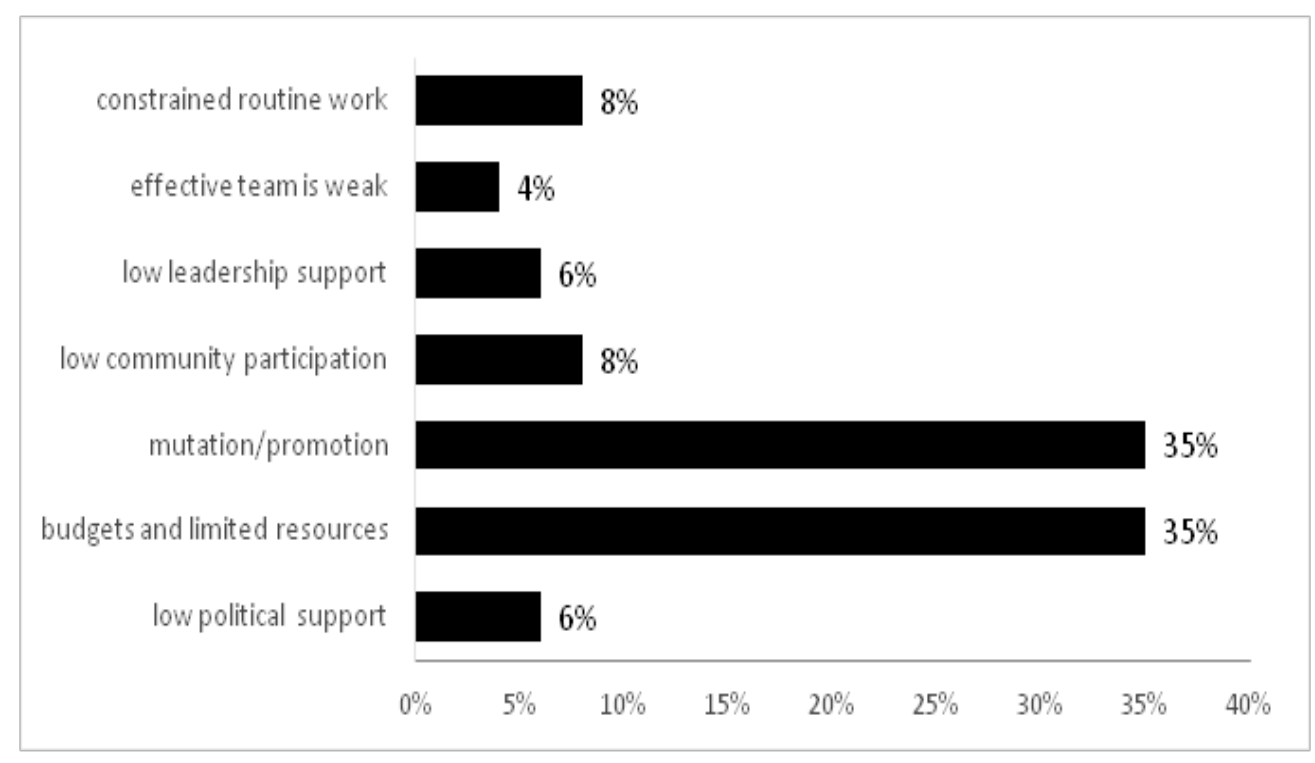

Source: Study of Mapping of Utilization of Post-Training Leadership Change Projects (PKP2A III, 2017) 
Research \& Developmnet institutions can be started by collecting innovation products from each work unit and from the project changes in the Leadership Training employee. Leadership training is a means to explore new innovations in order to solve problems in the public sector (LANRI, 2016b). The next step is to verify and group it so that it can be benchmarked and replicated elsewhere.

Approximately 80,000 innovations have been created from changes in leadership training projects at all levels, the involvement of a number of local governments in the LANinitiated Innovation Laboratory (LANRI, 2017b) and the INAGARA Award has been given to 26 districts/cities that have succeeded in developing public service innovations in their regions (LANRI, 2018). The role of innovation dissemination has been carried out by the State Administration Institute by organizing the INAGARA Award as an appreciation to the regional government of the Regional Organization which is highly committed to managing public services, with the innovation criteria: seeing the benefits and significant impacts, program sustainability, integrated broadly not only at the local locus but its replication up to the national level even to the world. This can be the first step so that the innovation of each region can be mapped in an information system and mapping in the regional innovation roadmap. In this context, the State Administration Innovation Information System is important to be implemented immediately.

Integration of innovation in the service system is needed because of the presence of a public service gap. Unity of innovation systems in various regions is integrated for mutual benefit which accelerates innovation in all regions, effective and efficient wheels of development in the region, and achieves the target of world-class bureaucracy in 2025 (LANRI, 2016a). In addition, awareness of innovation that is still sporadic, stagnant and tends to be unclear requires a 5-year plan to innovate with the presence of a bureaucratic innovation system reference in Indonesia that includes the construction of an innovation needs plan, organizational infrastructure readiness, strengthening innovation capacity, and monitoring and impact measurement (LANRI, 2016a). Facilitated by the presence of a perception index of innovation in public services as a reference for strengthening the performance of public service innovations on dimensions or elements that are seen as weak.

\section{Conclusion}

The regional government needs to establish or assign a unit of work/work-force in charge and responsible for implementing the State Administrative Innovation System (SINAGARA), with the research and Development Agency as the leading sector. The main tasks and functions of such work units/unit of work are; gather innovation programs from each agency, work units in the local government environment; interventing, selecting and categorizing innovation programs, based on the criteria of innovation; displays innovation programs in the media that can be easily accessed by the public; conducting socialization of the flagship innovation benchmark, in order to be replicated to other units of working units of similar/applicable; provide incentives and rewards to stimulate the development of innovations in the region.

As an incentive for innovator's work unit, given the opportunity to participate in innovation competitions in various institutions such as Inagara Awards (LANRI), Kalimantan Innovation Jamboree (PKP2A III LAN), Top Innovation 99, SINOVIK (KEMENPAN-RB), and so on. And, given the money coaching for innovator work units. Not only that, for an innovator agent is given incentives in the form of competency development such as promotion/rank and so on.

It takes political will regional head and high leadership in allocating the 
budget for the utilization of information technology in developing/expanding the State Administration's Innovation Information System (SINAGARA) in its region. Increase capacity for innovations in various scales including workshop innovations, innovations, curriculum classes innovations in various learning and training points, and so on.

\section{Acknowledgment}

First of all, thanks to Allah SWT for his mercy and guidance in giving me full strength to complete this research. Thank you very much to the organization I have been in, the State Administration Institute, and my family and associates in the support of material immaterial.

Thank you for our research partners who have contributed to the study of project mapping of post-training leadership changes, such as Mr. Mariman Darto as the head of the center and all participants in this research project.

\section{References}

Bekkers, V., \& Tummers, L. (2017). Perspectives on public sector reform: An innovation perspective. In S. Van de Walle \& S. Groeneveld (Eds.), Theory and Practice of Public Sector Reform (pp. 61-78). London: Routledge.

BPP Kemendagri. (2017). Kondisi dunia penelitian di Indonesia. Jakarta: Kemendagri.

Semangat Bantaeng keluar dari daerah tertinggal. (2018, February 6). Era.id Retrieved May 20, 2019, from https:// www.era.id/read/y6UYXd-semangatbantaeng-keluar-dari-daerah-tertinggal

Humas. (2017, September 27). Presiden teken PP Payung Hukum terhadap inovasi dalam penyelenggaraan Pemerintah Daerah. Retrieved May 15, 2019, from https://setkab.go.id/presiden-teken-pppayung-hukum-terhadap-inovasi-dalampenyelenggaraan-pemerintah-daerah/
Ismiatun. (2015). Pengembangan sistem inovasi dalam perspektif peningkatan daya saing daerah dengan pendekatan system dynamics. JISIP: Jurnal Ilmu Sosial dan Ilmu Politik, 4(2), 2442-6962.

LAN, P. I. (2018). 99 Inovasi PKP2A III LAN (M. Darto, Ed.). Samarinda, Kalimantan Timur: PKP2A III LAN.

LANRI. (2015). Inovasi administrasi negara harus terus didorong. Retrieved December 17, 2015, from http://lan.go.id/id/berita-lan/inovasiadministrasi-negara-harus-terus-didorong\#

LANRI. (2016a). Inovasi terintegrasi guna tingkatkan layanan publik. Retrieved May 20, 2019, from http://lan.go.id/id/beritalan/inovasi-terintegrasi-guna-tingkatkanlayanan-publik

LANRI. (2016b). Perlu banyak terobosan atasi kualitas pelayanan publik. Retrieved May 20, 2019, from http://lan.go.id/id/berita-lan/ perlu-banyak-terobosan-atasi-kualitaspelayanan-publik

LANRI. (2017a). ASN penting memanfaatkan teknologi informasi. Retrieved December 18, 2017, from http://lan.go.id/id/berita-lan/ asn-penting-memanfaatkan-teknologiinformasi

LANRI. (2017b). Pemerintah perbaiki berbagai sektor pelayanan publik. Retrieved May 20, 2019, from http://lan.go.id/id/berita-lan/ pemerintah-perbaiki-berbagai-sektorterkait-pelayanan-publik

PKP2A III, L. (2016). Prospek pembentukan lembaga litbang daerah kabupaten kota di Provinsi Kalimantan Timur. Retrieved December 18, 2017, from https://www. slideshare.net/PKP2AIIILANSamarinda/ prospek-pembentukan-lembaga-litbangdaerah-kabupatenkota-di-provinsikalimantan-timur

PKP2A III, L. (2017). Kajian pemetaan kemanfaatan proyek perubahan pasca diklat kepemimpinan. Retrieved from https://www. researchgate.net/publication/323004901_ Kajian_Pemetaan_Kemanfaatan_ 
Proyek_Perubahan_Pasca_Diklat_ Kepemimpinan?_sg=Z1FxHSizV1b9 _5TWMyFEMufg8o366HyLHxIXN9_ gf4a763iiiKVBRLJ2-OTSXIcjm41V7o3RP 3POaFFe0i1sekRL1FByOPtYPpQZaQp3. fhoymMEE68QDJrYeNn0MZiPF

Sartika, D. (2015). Inovasi organisasi dan kinerja organisasi: Studi kasus pada pusat kajian dan pendidikan dan Pelatihan Aparatur III Lembaga Administrasi Negara. Jurnal Borneo Administrator, 11(2), 129-151.
Simbolon, F. T. (2017). Saatnya inovasi daerah. Retrieved May 20, 2019, from http://harian.analisadaily. com/opini/news/saatnya-inovasidaerah/442424/2017/10/31

Suwarno, Y. (2008). Inovasi di sektor publik. Jakarta: STIA-LAN Press.

Utomo, T. W. W. (2017). Inovasi harga mati: Sebuah pengantar inovasi administrasi negara (1st ed.). Jakarta: Raja Grafindo Persada. 